\title{
Perspective
}

\section{Booster dose against COVID-19- An important tool in the fight against the SARS-CoV-2}

\author{
Sankalp Yadav $1, *$ \\ ${ }^{1}$ Dept. of Medicine \& Tuberculosis, Shri Madan Lal Khurana Chest Clinic, Moti Nagar, NDMC, New Delhi, India
}

\section{A R T I C L E I N F O}

Article history:

Received 26-12-2021

Accepted 30-12-2021

Available online 31-12-2021

\begin{abstract}
This is an Open Access (OA) journal, and articles are distributed under the terms of the Creative Commons Attribution-NonCommercial-ShareAlike 4.0 License, which allows others to remix, tweak, and build upon the work non-commercially, as long as appropriate credit is given and the new creations are licensed under the identical terms.
\end{abstract}

For reprints contact: reprint@ipinnovative.com
The present pandemic of coronavirus disease 2019 (COVID-19) caused by the severe acute respiratory syndrome coronavirus 2 (SARS-CoV-2) has instilled fear among the authorities and the general public. ${ }^{1}$ The disease that is caused by a positive-stranded RNA virus which is mutating at a very fast rate has led to panic in several countries across the globe. ${ }^{2}$ The latest reports of 'B.1.1.529' or Omicron variant of SARS-CoV-2 and a surge in the number of cases due to this variant has already put the healthcare facilities at an alert. $^{3}$ The cases due to this variant of concern (VOC) as designated by the WHO are rising exponentially. ${ }^{4}$ First reported from South Africa on $24^{\text {th }}$ November 2021, it has been reported in over 108 countries. ${ }^{4,5}$ To date, there are more than 1.5 million cases worldwide due to this new VOC of SARS-CoV-2 with 26 deaths. ${ }^{5}$ This VOC is also affecting even those individuals who have already taken two doses of the COVID-19 vaccines. ${ }^{6}$ The situation is gruesome and demands a need for immunity boost by a booster dose of the COVID-19 vaccines.

Few developed countries like Israel have already started this long ago and are even starting the fourth jab for their citizens however the majority of the countries are lagging in this due to policy differences in the use of booster shots of the COVID-19 vaccine. ${ }^{7}$ This situation is mostly common in highly populated countries of Asia and Africa. ${ }^{8}$ Lack

\footnotetext{
* Corresponding author.

E-mail address: drsankalpyadav@gmail.com (S. Yadav).
}

of clear and timely policies for giving a booster shot to the population could wreak havoc on the fragile healthcare systems of these countries. ${ }^{8}$ It has been reported that the immunity due to the COVID-19 vaccines lasts for about six to seven months. ${ }^{9}$ The booster doses could increase this to $75 \%-85 \% .^{10,11}$ Thus, it is extremely important to include the booster dose of the COVID-19 vaccines for ensuring an appropriate amount of immunity in those individuals who have taken their two doses a long time back. ${ }^{11}$

The latest reports from countries like India where a 'Precaution dose' is to be started for the frontline workers and at-risk individuals with comorbidities above the age of 60 years is an important and welcome decision in the fight against the COVID-19. ${ }^{12}$ This vaccination drive will start on 10 January $2022 .{ }^{12}$ SARS-CoV-2 is an RNA virus and has a tendency to mutate. ${ }^{13}$ The current variant of this virus is said to be mutated 30 times. ${ }^{13}$ Due to these large number of mutations, it is reported that the virus has become more transmissible and could evade the immunity provided by the COVID-19 vaccines. ${ }^{13}$ However, these reports are largely based on the facts available from the countries like South Africa where the cases of Omicron variant have risen at a very fast rate and further studies are essential to establish these facts. ${ }^{4}$ Overall, a booster dose will help in preventing large-scale morbidity and mortality as seen due to SARSCoV-2 since it was first identified in Wuhan, China. ${ }^{1}$

Again, immunization of the children is extremely important. And a number of countries are yet to vaccinate 
their younger population against this omnipresent virus i.e., SARS-CoV-2. And the latest reports of India starting vaccination for children of age 15 years and above will also begin from January 3, 2022. ${ }^{13}$ The largest vaccination program against COVID-19 was started in India on January $16^{t h}, 2021 .^{13}$ To date, the country has vaccinated $90 \%$ of the adult population with a single dose of COVID-19 vaccines and around $61 \%$ population of both the doses against the SARS-CoV-2. ${ }^{13}$ Remarkably, the latest development of vaccination drive for children is a very important step in the fight against a rapidly mutating virus.

In short, the rapid rise of the Omicron variant of SARSCoV-2 demands multiple initiatives from governments across the globe. The policy decision by the Indian government to give 'Precaution dose' to its frontline workers and at-risk individuals with comorbidities above the age of 60 years is a great step towards the country's fight against the pandemic of COVID-19. And the inclusion of children above the age of 15 years will be a boon in the current time. Large-scale epidemiological studies are imperative to determine the real impact of booster doses. Furthermore, the role of all the stakeholders involved in the management of COVID-19 is very important for successful vaccination campaigns especially in countries with a huge population.

\section{Acknowlegements}

None.

\section{Conflict of Interests}

There are no conflicts of interests

\section{Source of Funding}

None.

\section{References}

1. Yadav S, Rawal G. The mental health status of the general public and healthcare professionals in the COVID-19 pandemic. IP Indian J Immunol Respir Med. 2020;5(2):72-4.

2. Hewings-Martin Y. Is there more than one strain of the new coronavirus? Available from URL:- https://www.medicalnewstoday .com/articles/is-there-more-than-one-strain-of-the-new-coronavirus. Last accessed 2021 on December 26.

3. WHO. Update on Omicron. Available from URL:- https://www.who $\mathrm{int} / \mathrm{news} /$ item/28-11-2021-update-on-omicron. Last accessed 2021 on December 26.

4. WHO. Classification of Omicron (B.1.1.529): SARS-CoV-2 Variant of Concern. Available from URL:- https://www.who.int/news/item/26 -11-2021-classification-of-omicron-(b.1.1.529)-sars-cov-2-variant-of -concern. Last accessed 2021 on December 26.

5. Omicron spread: 108 countries and over 1.5 lakh patients in a month. Available from URL:- https://www.hindustantimes.com/world-news/ omicron-spread-108-countries-and-over-1-5-lakh-patients-in-a-mont h-101640398862101.html. Last accessed 2021 on December 26.

6. 183 Omicron cases analysed, 87 were fully vaccinated: Government. Available from URL:- https://timesofindia.indiatimes.com/india/183omicron-cases-analysed-87-were-fully-vaccinated-government/articl eshow/88482756.cms. Last accessed 2021 on December 26.

7. Israeli PM announces fourth Covid jab for over-60s to tackle Omicron. Available from URL:- https://www.theguardian.com/world/2021/dec/ 21/israeli-pm-announces-fourth-covid-jab-for-over-60s-to-tackle-omi cron. Last accessed 2021 on December 26.

8. Factbox: Countries weigh need for booster COVID-19 shots. Available from URL:- https://www.reuters.com/business/healthcare-pharmaceut icals/countries-weigh-need-booster-covid-19-shots-2021-09-24/. Last accessed 2021 on December 26.

9. Dolgin E. COVID vaccine immunity is waning - how much does that matter? Nature. 2021;597:606-7.

10. Ginsberg L. Why Covid vaccine booster shots are so important: Omicron will 'rip right through the population,' says expert. Available from URL:- https:/www.cnbc.com/2021/12/21/omicron-expert-wh y-covid-vaccine-booster-shots-are-so-important.html. Last accessed 2021 on December 26.

11. Roberts M. Booster at least $80 \%$ effective against severe Omicron. Available from URL:- https://www.bbc.com/news/health-59696499. Last accessed 2021 on December 26.

12. $\mathrm{PM}$ announces booster shots for frontline workers, 60 -plus population; vaccination also to begin for 15-18 age group. Available from URL:- $h$ ttps://www.newindianexpress.com/nation/2021/dec/25/pm-announce s-boostershots-for-frontline-workers-60-plus-population-vaccinationalso-to-begin-for-15-2399717.html. Last accessed 2021 on December 26.

13. PTI. Omicron variant reportedly has over 30 mutations in spike protein, may bypass vaccines: AIIMS chief. Available from URL:- htt ps://www.indiatoday.in/coronavirus-outbreak/story/omicron-varianteportedly-has-30-mutations-in-spike-protein-may-bypass-vaccines-ai ims-chief-randeep-guelria-1881833-2021-11-28. Last accessed 2021 on December 26.

Cite this article: Yadav S. Booster dose against COVID-19- An important tool in the fight against the SARS-CoV-2. IP Indian J Immunol Respir Med 2021;6(4):210-211. 